\title{
Review Article \\ Potential Effects of Medicinal Plants and Secondary Metabolites on Acute Lung Injury
}

\author{
Daniely Cornélio Favarin, ${ }^{1}$ Jhony Robison de Oliveira, ${ }^{1}$ \\ Carlo Jose Freire de Oliveira, ${ }^{2}$ and Alexandre de Paula Rogerio ${ }^{1}$ \\ ${ }^{1}$ Departamento de Clínica Médica, Laboratório de ImunoFarmacologia Experimental, Instituto de Ciências da Saúde, \\ Universidade Federal do Triângulo Mineiro, Rua Manoel Carlos 162, 38025-380 Uberaba, MG, Brazil \\ ${ }^{2}$ Instituto de Ciências Biológicas e Naturais, Universidade Federal do Triângulo Mineiro (UFTM), Uberaba, MG, Brazil \\ Correspondence should be addressed to Alexandre de Paula Rogerio; alexprogerio@biomedicina.uftm.edu.br
}

Received 3 May 2013; Revised 16 August 2013; Accepted 23 August 2013

Academic Editor: Edineia Lemos de Andrade

Copyright (C) 2013 Daniely Cornélio Favarin et al. This is an open access article distributed under the Creative Commons Attribution License, which permits unrestricted use, distribution, and reproduction in any medium, provided the original work is properly cited.

\begin{abstract}
Acute lung injury (ALI) is a life-threatening syndrome that causes high morbidity and mortality worldwide. ALI is characterized by increased permeability of the alveolar-capillary membrane, edema, uncontrolled neutrophils migration to the lung, and diffuse alveolar damage, leading to acute hypoxemic respiratory failure. Although corticosteroids remain the mainstay of ALI treatment, they cause significant side effects. Agents of natural origin, such as medicinal plants and their secondary metabolites, mainly those with very few side effects, could be excellent alternatives for ALI treatment. Several studies, including our own, have demonstrated that plant extracts and/or secondary metabolites isolated from them reduce most ALI phenotypes in experimental animal models, including neutrophil recruitment to the lung, the production of pro-inflammatory cytokines and chemokines, edema, and vascular permeability. In this review, we summarized these studies and described the anti-inflammatory activity of various plant extracts, such as Ginkgo biloba and Punica granatum, and such secondary metabolites as epigallocatechin-3-gallate and ellagic acid. In addition, we highlight the medical potential of these extracts and plant-derived compounds for treating of ALI.
\end{abstract}

\section{Introduction}

Acute lung injury (ALI) and its severe form, acute respiratory distress syndrome (ARDS), were first described in 1967 by Ashbaugh et al. [1] in patients with acute onset of tachypnea and hypoxia and the loss of compliance after a variety of stimuli [2-5]. According to the American-European Consensus Conference (AECC) ARDS was recognized as the most severe form of acute lung injury (ALI), a form of diffuse alveolar injury. In addition, the Berlin definition modified the AECC definition and divided ALI into the independent categories of ALI non-ARDS and ARDS alone [6, 7]. ALI is a lifethreatening syndrome that causes high morbidity and mortality [8-12]; however, the worldwide incidence is variable, reaching, for example, 64.2 to 78.9 cases $/ 100,000$ personyears in the United States and 17 cases $/ 100,000$ personyears in Northern Europe, with an estimated 74,500 deaths annually [13]. Patients admitted to intensive care units are most affected by ALI (1 in 10) [14]. However, individuals with multiple comorbidities, chronic alcohol abuse, or chronic lung disease also present a high risk of developing ALI [15, 16]. The causes of ALI may be direct, such as pneumonia, inhalation injury, aspiration of gastric contents, inhalation injury, chest trauma, and near drowning, or indirect, such as sepsis, burns, pancreatitis, fat embolism, hypovolemia, and blood transfusion $[8,14]$. The pathogenesis of ALI involves increased permeability of the alveolar-capillary membrane, accumulation of protein-rich fluid in the airspaces, pulmonary edema, and pulmonary infiltration of neutrophils, mainly bilateral, resulting in poor lung compliance, diffuse alveolar damage, and, consequently, acute hypoxemic respiratory failure $[8,17-23]$.

The inflammatory process of ALI can be classified into three stages: exudative, proliferative, and fibrotic stages [4, 
$9,14]$. The exudative stage is characterized by intense neutrophilic infiltrate, edema, and protein-rich fluid due to pulmonary capillary leakage [14]. The proliferative stage ensues as a consequence, the development of which is marked by proliferation and phenotypic changes in type II alveolar cells and fibroblasts [20]. In the absence of recovery, the fibrotic stage develops, which is characterized by diffuse fibrosis and modulation of the structural architecture remodeling of the lung. These stages characterize the chronic phase of ALI, leading to the formation of fibrotic scarring in the lung $[9,14]$.

Although inflammation is essential for the maintenance of tissue homeostasis and protection against infections, uncontrolled inflammation may contribute to lung damage, a characteristic phenomenon of several inflammatory disorders, including ALI [24-26]. In ALI airway inflammation, neutrophils are the first cells to be recruited and are the predominant cause of tissue damage [25, 27, 28], and their persistence is associated with a poor ALI prognosis [2729]. The increased accumulation of neutrophils is associated with the exacerbation/amplification of inflammation and, consequently, of lung lesions due to the release of a complex network of proinflammatory mediators, such as cytokines (interleukin (IL)-1 $\beta$, tumor necrosis factor (TNF)- $\alpha$, IL-6, and IL-8), chemokines chemokine (C-X-C motif) ligand (CXCL)-8, CXCL-1, CXCL-5, and chemokine (C-C motif) ligand (CCL)-2), proteases (elastases, collagenases, cathepsin $\mathrm{G}$, and metalloproteinases), and oxidants (hydrogen peroxide and superoxide), and the accumulation of necrotic material [4, 24-26, 28-31]. Interestingly, an increase in such antiinflammatory cytokines as IL-10 is also observed in ALI [32-34]. Thus, the balance of proinflammatory and antiinflammatory mediators could coordinate the evolution or resolution of ALI. The resolution of inflammation is an active process and requires the activation of endogenous mechanisms, such as the biosynthesis of lipid mediators with proresolution activity, interaction between cells (hematopoietic and/or structural cells), and activation of cellular processes (e.g., apoptosis, phagocytosis) to maintain homeostasis [35-38]. Resolution includes the steps of (a) the inhibition of polymorphonuclear cell (neutrophil) infiltration, (b) return to normal vascular permeability, (c) clearance of polymorphonuclear cells (mainly by apoptosis), (d) infiltration of monocytes/alternatively activated macrophages, and (e) removal of apoptotic neutrophils, microorganisms, allergens, and foreign agents by macrophages [36, 38-42]. Clearly, resident and recruited macrophages play an important role in the clearance of injured tissues, debris, and apoptotic cells and are therefore important for the resolution of inflammation $[36,38]$. Specifically, the resolution in ALI is characterized by the removal of neutrophils in the lung and the restoration of epithelial barrier function [38, 43]. Animal models have not been developed that fully to resemble human ALI but are quite useful for the better understanding of airway inflammation and the development of ALI $[18,44]$. ALI experimental models in mouse, rat, rabbit, and guinea pigs are reported in the literature using different triggers, such as lipopolysaccharide (LPS), live bacteria, acid aspiration, and others. A more detailed description of the most commonly used ALI models and their characteristics can be found in Table 1.
The considerable progress made through the use of molecular and cellular assays together with knockout and transgenic animals has contributed significantly to the understanding of the genetic, tissue-specific, and immunological factors that contribute to the development of ALI [45-52]. Nevertheless, no therapeutic agents have demonstrated a clear benefit in ALI treatment [41], and corticosteroids have been used for treatment of ALI for many years [18, 53]. Besides, the disappointing results of a series of clinical trials treatment of ALI or patients at risk for ARDS using corticosteroids as well as the increase of the risk of infection and other adverse effects, the administration of corticosteroids might improve the injured tissue due to their anti-inflammatory effect [54]. Thus, the development of new compounds that exhibit similar therapeutic potential with reduced adverse effects is necessary for the continuous treatment of ALI. Furthermore, agents of natural origin that induce very few side effects should be considered for use as therapeutic substitutes or as complementary treatments to existing therapies. In addition, natural compounds may even form the basis of new drugs for the treatment of diseases [55-58]. In the course of a continued search for bioactive natural products derived from plants (secondary metabolites), several groups, including our own, have successfully employed experimental models to screen the pharmacologic activities of plant extracts and isolated compounds (secondary metabolites) [59-62]. Within this context, we and others have demonstrated that many plant extracts and secondary metabolites have the potential to be used in ALI treatment $[8,60,63]$. In a clinical trial in patients with severe pulmonary hypertension during extracorporeal circulation, Xu et al. [64] demonstrated that composite Rhodiolae (herbal plant) reduced the occurrence rate of acute lung injury and its mortality. In addition other studies were carried out with plant extracts (Table 2) and plantderived substances (Table 3) in ALI experimental models.

Ginkgo biloba L. (Ginkgoaceae) is one of the most well-known plants in Chinese culture and has been used for therapeutic purposes for approximately 1,000 years. Its extracts are marketed worldwide to prevent or delay cognitive impairment associated with aging or neurodegenerative disorders $[62,65,66]$. In addition, $G$. biloba leaves have been used for the treatment of airway diseases, such as asthma and bronchitis [67]. In a bleomycin-induced acute lung injury rat model, a G. biloba leaf extract (EGb 761) reduced the responsiveness and diminished the occurrence of further reduction in the vasoconstrictor response of the pulmonary artery due to 5-hydroxytryptamine (5-HT). Furthermore, EGb 761 normalized bleomycin-induced alterations in the measured lung tissue biochemical markers [68]. Additionally, in another study, EGb 761 reduced protein leakage, neutrophil infiltration, myeloperoxidase (MPO, a heme enzyme present in the primary granules of neutrophils), and metalloproteinase (MMP)-9 activities in an LPS-initiated ALI rat model. These effects were associated with an inhibition of the activation of the nuclear factor-kappa B $(\mathrm{NF}-\kappa \mathrm{B})$ pathway. In LPSinduced acute lung injury rat model, G. biloba extract reduced the recruitment of leukocytes to bronchoalveolar lavage fluid (BALF) and the pulmonary permeability. In addition, besides reducing other parameters, $G$. biloba extract also reduced the 
TABLE 1: Animal models of lung injury.

\begin{tabular}{|c|c|c|c|}
\hline Model & Characteristic inflammation & Animals & References \\
\hline Acid aspiration & $\begin{array}{l}\text { Rupture of the alveolar-capillary barrier with } \\
\text { intense neutrophilic infiltrate }[23,56,105,106]\end{array}$ & $\begin{array}{l}\text { Mice } \\
\text { Rats } \\
\text { Rabbits }\end{array}$ & {$[42,56,107-110]$} \\
\hline Bleomycin & $\begin{array}{l}\text { Acute inflammatory injury, and reversible fibrosis } \\
{[23,111]}\end{array}$ & $\begin{array}{l}\text { Mice } \\
\text { Rats }\end{array}$ & $\begin{array}{l}{[112-114]} \\
{[20,115]}\end{array}$ \\
\hline $\begin{array}{l}\text { Cecal ligation and } \\
\text { puncture }\end{array}$ & $\begin{array}{l}\text { Variable neutrophilic alveolar infiltrate and } \\
\text { increased permeability }[23,43]\end{array}$ & $\begin{array}{l}\text { Mice } \\
\text { Rats }\end{array}$ & $\begin{array}{l}{[111,116,117]} \\
{[118-120]}\end{array}$ \\
\hline Hyperoxia & $\begin{array}{l}\text { Epithelial injury and neutrophilic infiltration, } \\
\text { followed by type II cell proliferation and scarring } \\
{[23,121-123]}\end{array}$ & $\begin{array}{l}\text { Mice } \\
\text { Rats }\end{array}$ & $\begin{array}{l}{[124-127]} \\
\quad[128]\end{array}$ \\
\hline Intrapulmonary bacteria & $\begin{array}{l}\text { Increased neutrophilic alveolar infiltrate, } \\
\text { interstitial edema, and permeability }[23,129]\end{array}$ & Rabbits & {$[129]$} \\
\hline Intravenous bacteria & $\begin{array}{l}\text { Interstitial edema, neutrophils sequestration, and } \\
\text { intravascular congestion }[23,130]\end{array}$ & Mice & {$[131]$} \\
\hline LPS & $\begin{array}{l}\text { Neutrophilic inflammation with increased } \\
\text { intrapulmonary cytokines }[20,23,132]\end{array}$ & $\begin{array}{l}\text { Mice } \\
\text { Rats } \\
\text { Sheep }\end{array}$ & $\begin{array}{c}{[20,45,59,70,132-} \\
135] \\
{[136]}\end{array}$ \\
\hline $\begin{array}{l}\text { Nonpulmonary } \\
\text { ischemia/reperfusion }\end{array}$ & $\begin{array}{l}\text { Increased microvascular permeability, neutrophils } \\
\text { recruitment, edema, and sequestration in the } \\
\text { lungs }[23,28]\end{array}$ & $\begin{array}{l}\text { Mice } \\
\text { Rats }\end{array}$ & {$[28,137-139]$} \\
\hline Oleic acid & $\begin{array}{l}\text { Neutrophilic inflammation, increased } \\
\text { permeability, and edema }[22,23,140]\end{array}$ & $\begin{array}{l}\text { Mice } \\
\text { Rats }\end{array}$ & {$[21,22,142]$} \\
\hline $\begin{array}{l}\text { Peritonitis by cecal } \\
\text { ligation } \\
\text { and puncture }\end{array}$ & $\begin{array}{l}\text { Variable degrees } \\
\text { Neutrophilic alveolar infiltrate } \\
\text { and increased permeability }[23,143]\end{array}$ & $\begin{array}{c}\text { Rats } \\
\text { Rabbits }\end{array}$ & $\begin{array}{l}{[143,144]} \\
\quad[44]\end{array}$ \\
\hline $\begin{array}{l}\text { Pulmonary } \\
\text { ischemia/reperfusion }\end{array}$ & $\begin{array}{l}\text { Increased pulmonary vascular permeability, } \\
\text { neutrophil infiltration, and edema }[23,145]\end{array}$ & $\begin{array}{l}\text { Mice } \\
\text { Rats } \\
\text { Rabbits }\end{array}$ & $\begin{array}{l}{[145-147]} \\
{[148]}\end{array}$ \\
\hline
\end{tabular}

TABLE 2: Plants with anti-inflammatory effect on ALI.

\begin{tabular}{|c|c|c|c|c|}
\hline Plant & Model of ALI & Doses & Relevant findings & Reference \\
\hline Bathysa cuspidata & ALI in rats induced by Paraquat & 200 and $400 \mathrm{mg} / \mathrm{kg}$ & $\downarrow$ Lung edema & [149] \\
\hline Ginkgo biloba & ALI in mice induced by LPS & 10,100 , and $1000 \mathrm{mg} / \mathrm{kg}$ & $\begin{array}{l}\downarrow \text { Leukocytes, PMN, } \\
\mathrm{MPO} \text {, and NF- } \kappa \mathrm{B}\end{array}$ & {$[150]$} \\
\hline $\begin{array}{l}\text { Panax } \\
\text { notoginseng }\end{array}$ & $\begin{array}{l}\text { ALI in rats induced by intestinal } \\
\text { ischemia/reperfusion }\end{array}$ & $100 \mathrm{mg} / \mathrm{kg}$ & $\begin{array}{l}\downarrow \text { Leukocytes, PMN, } \\
\text { MPO, IL- } 8 \text {, and TNF- } \alpha\end{array}$ & {$[151]$} \\
\hline Sho-seiryu-to & $\begin{array}{l}\text { ALI in guinea pigs induced by oleic } \\
\text { acid }\end{array}$ & 3 and $0.75 \mathrm{~g} / \mathrm{kg}$ & $\begin{array}{l}\downarrow \text { Leukocytes and total } \\
\text { protein }\end{array}$ & {$[152]$} \\
\hline Viola yedoensis & ALI in mice induced by LPS & 2,4 , and $8 \mathrm{mg} / \mathrm{kg}$ & $\begin{array}{l}\downarrow \text { Leukocytes, total } \\
\text { protein, lung edema, and } \\
\text { MPO }\end{array}$ & {$[153]$} \\
\hline
\end{tabular}

blood TNF- $\alpha$ concentration and MPO in lung tissues [69]. Therefore, G. biloba appears to have potential to be used in the treatment of inflammation in ALI.

Another plant with antineutrophilic potential is Lafoensia pacari Jaumes St. Hilaire (Lythraceae), the extract of which is traditionally used by the population of Mato Grosso state, Brazil, to treat inflammation and gastric ulcers $[70,71]$. In a clinical trial, however, L. pacari methanolic extract failed to eradicate Helicobacter pylori in dyspeptic urease-positive patients, even though the extract was well tolerated, and about $74 \%$ of patients had partial improvement of dyspnea, and $42 \%$ had full improvement of dyspnea in patients treated with extract of L. pacari [72]. Employing the asthma model induced by $T$. canis infection or the ovalbumin-induced asthma model, our group demonstrated that oral treatment with an ethanolic extract of $L$. pacari decreased the number of eosinophils and neutrophils recruited to BALF [73, 74]. In an attempt to identify the molecule(s) responsible for the antieosinophil and antineutrophil activity of the $L$. pacari extract, we used a mouse model of peritonitis induced by exposure to the $\mathrm{F} 1$ fraction of the $H$. capsulatum yeast wall [75]. This model of acute and localized eosinophilia and neutrophilia was suitable for the bioassay-guided fractionation of the L. pacari extract, and we were able to isolate and 


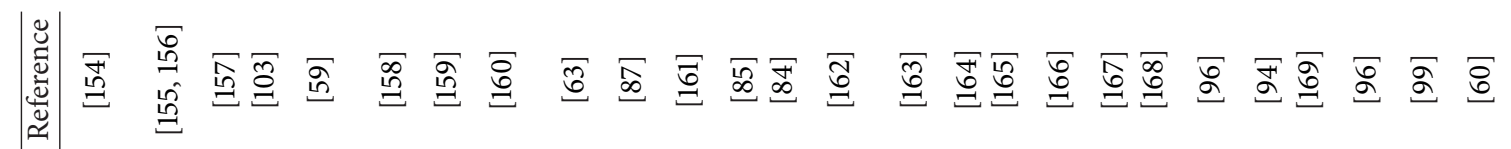

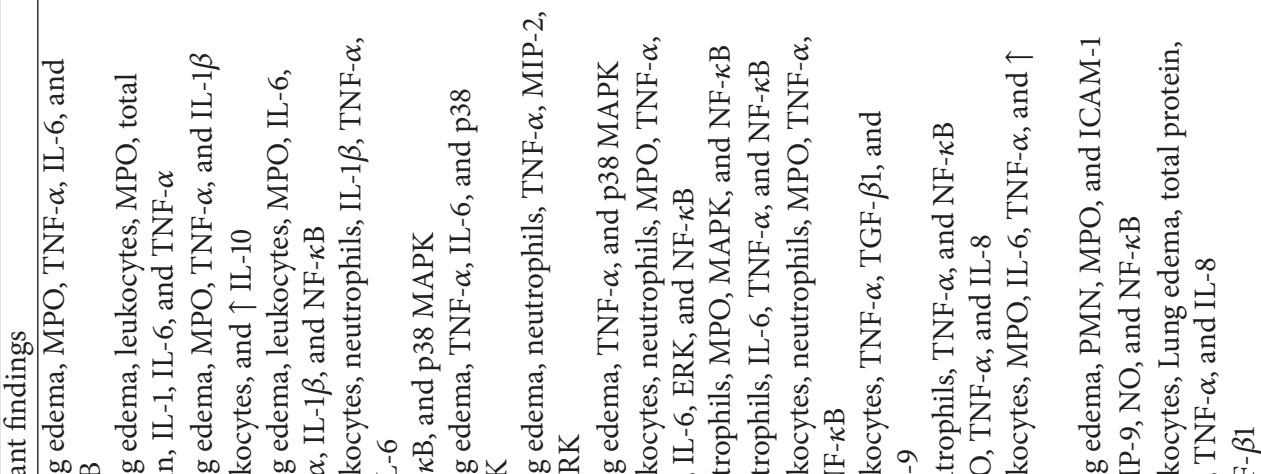

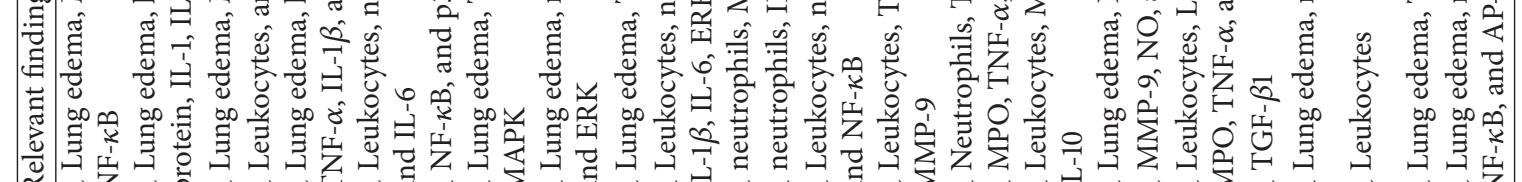

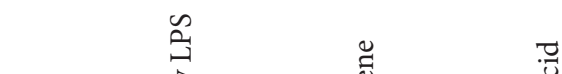

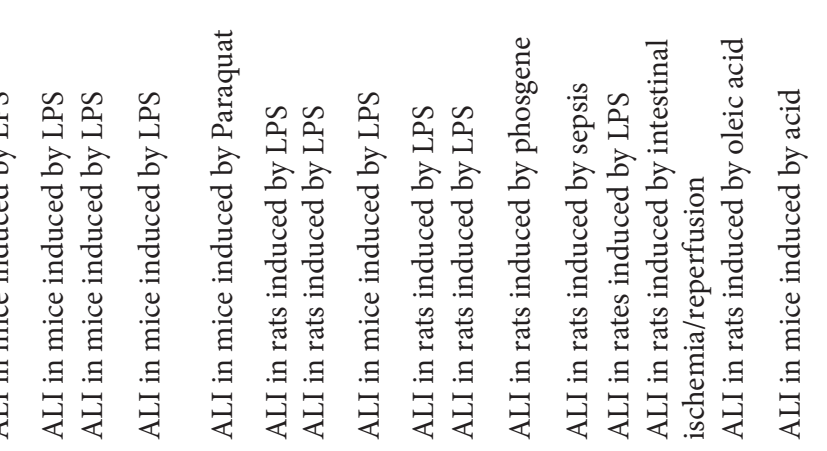

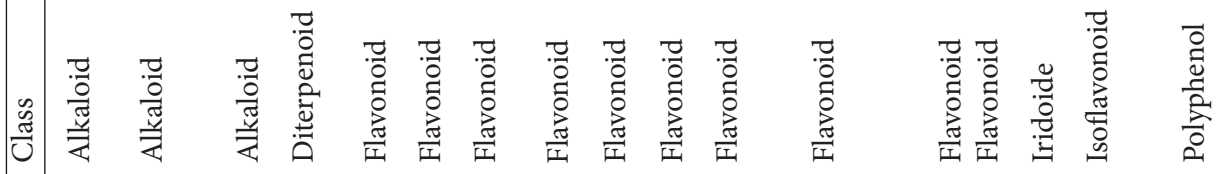




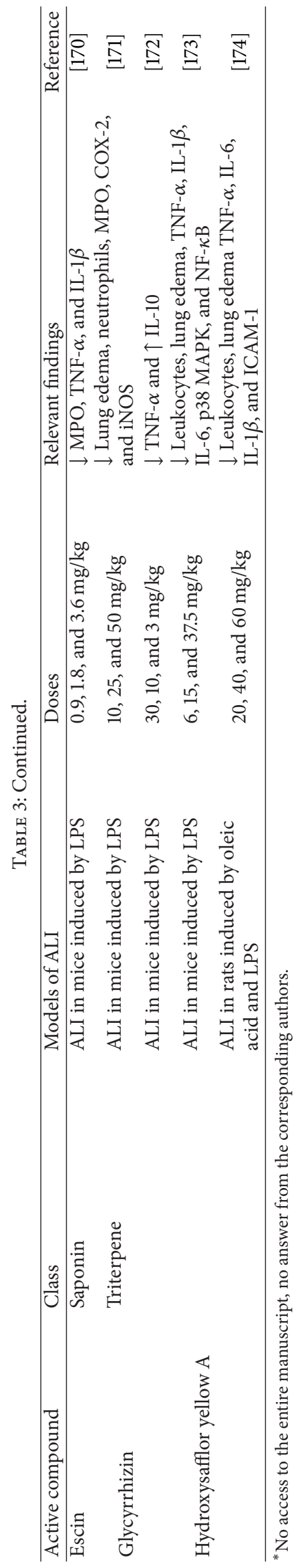


chemically characterize ellagic acid (a polyphenol) as the major active component in the extract [61]. We showed that L. pacari extract as ellagic acid was able to reduce the number of eosinophils and neutrophils in this model [62]. We recently demonstrated that ellagic acid displayed anti-inflammatory properties by decreasing the severity of $\mathrm{HCl}$ acid-initiated ALI, accelerating the resolution of inflammation, and decreasing the cyclooxygenase-2 (COX-2) inhibitor-induced exacerbation of inflammation [60]. Ellagic acid reduced several inflammatory parameters, including vascular permeability alterations and neutrophil recruitment to BALF and the lung. In addition, ellagic acid reduced the proinflammatory cytokine IL- 6 and increased the anti-inflammatory cytokine IL-10 in BALF without downregulating the NF- $\kappa \mathrm{B}$ and activator protein 1 (AP-1) signaling pathways [60].

Pomegranate (Punica granatum) extracts, which have been used for centuries for medical purposes, contain also ellagic acid, and studies with pomegranate extract have demonstrated the anti-inflammatory effects in an experimental model of ALI (LPS-initiated) by reducing MPO in the lungs of mice [76]. Together, these findings suggest that ellagic acid has potential anti-inflammatory effects for the resolution of ALI inflammation.

Flavonoids are the best studied class of plant metabolites. Indeed, the search term "flavonoids" yielded more than 64,786 entries in the U.S. National Library of Medicine's Medline database accessed using PubMed in May 2013. Flavonoids occur naturally in fruits and vegetables, such as onions, apples, grapes, and nuts and are therefore commonly part of the human diet [77]. These compounds are also a component of disease treatment (phytotherapy), as they are present in the seeds, stems, barks, roots, and/or flowers of several medicinal plants [78]. Flavonoids have shown a wide range of therapeutic properties in clinical and preclinical studies, including, but not limited to, antioxidant, anticancer, antiinflammatory, and antiallergy activities [79-82]. Luteolin, a widely distributed flavonoid, has been reported to exhibit anti-inflammatory, antioxidant, and anticarcinogenic activities [83]. Luteolin was reported to reduce several hallmarks of ALI (LPS-initiated): leukocyte infiltration, histological changes, lung tissue edema, protein extravasation, MPO activity in lung tissue, TNF- $\alpha$, keratinocyte-derived chemokine (KC), IL-6, and intercellular cell adhesion molecule-1 (ICAM-1) production, as well as inducible nitric oxide synthase (iNOS) and COX-2 expression in the lung [84]. Additionally, the expression of surface markers CD11b and Ly6G on neutrophils was reduced [85]. Luteolin also reduced N-Formylmethionyl-leucyl-phenylalanine (fMLP)induced neutrophil chemotaxis and respiratory burst after LPS challenge and reduced LPS-induced activation of the NF$\kappa \mathrm{B}$ pathway, possibly via mitogen-activated protein (MAP) kinase (MAPK) and serine/threonine-protein kinases (AKT) [86]. These findings suggest that luteolin has potential antiinflammatory effects for ALI treatment.

Green tea, from Camellia sinensis L. (Theaceae), is widely consumed around the world and is prepared by drying and steaming fresh tea leaves. Flavonoids are the major secondary metabolites found in green tea, with epigallocatechin3-gallate being the most abundant. In acute lung injury induced by oleic acid in mice, epigallocatechin-3-gallate reduced the lung index, blood TNF- $\alpha$ concentration, and the phosphorylation of p38 MAPK [87]. In another study using LPS-initiated ALI in mice, epigallocatechin-3-gallate demonstrated an anti-inflammatory effect by reducing neutrophil recruitment in the lung and the production of TNF- $\alpha$ and macrophage inflammatory protein (MIP)-2, most likely via reduced extracellular-signal-regulated kinase (ERK)1/2 and c-Jun N-terminal kinase (JNK) phosphorylation in the lungs [63]. Therefore, epigallocatechin-3-gallate might constitute an attractive molecule with potential interest for the treatment of ALI.

The discovery of curcumin, the principal pigment of turmeric, dates from approximately two centuries ago when Vogel and Pelletier isolated a pigment of "yellow coloring matter" from the rhizomes of Curcuma longa (turmeric) [8891]. Curcumin is present in the human diet and has been consumed for medicinal purposes for thousands of years [92]. This polyphenol has been shown to possess activities in the animal models of many human diseases. Curcumin modulates various molecules, including transcription factors, adhesion molecules, cytokines, and chemokines [92]. Curcumin demonstrated a significant anti-inflammatory effect with a reduction of the main ALI phenotypes, which included the reduction of neutrophil recruitment and activation, lung edema, inflammatory, and cytokines, most likely via a reduction of the NF- $\kappa \mathrm{B}$ pathway in several ALI models. These models include sepsis-induced acute lung injury induced by cecal ligation and puncture surgery $[93,94]$, aspiration of polyethylene glycol and activated charcoal [95], intestinal ischemia/reperfusion (I/R) [96], bleomycin-induced lung injury [97], acute inflammation by Klebsiella pneumonia introduction [98], oleic acid-induced ALI [99], and LPSinduced acute lung injury [100]. These findings suggest that curcumin could be an interesting alternative for the ALI treatment.

The alkaloid theophylline is one of the oldest drugs in use in the management of obstructive airway diseases of diverse etiologies [101, 102], despite its weakness as a bronchodilator. However, the use of this alkaloid is often limited due to concerns regarding dose-related adverse effects, numerous drug interactions, and a narrow therapeutic index. In a chronic inflammatory lung injury model induced by LPS in guinea pigs, theophylline improved the airway injury and airway hyperreactivity induced by the repetitive exposure to LPS [103]. These findings suggest that theophylline has potential anti-inflammatory effects for the treatment of ALI inflammation.

In conclusion, ALI is a disease with high morbidity and mortality, and the current disease outcome has yet to be improved by pharmacologic treatment. Natural products and plant derivatives used in folk medicine are of vast medical importance due to their potential as a source of molecules with pharmacologic properties. Although active plant-derived secondary metabolites can be randomly discovered, the process is laborious, with a success rate on the order of 1 new product per 10,000 plants screened $[62,104]$. In this review, we reviewed the effect of some plant extracts and their components on ALI experimental 
models. The important benefits obtained with curcumin, ellagic acid, and Ginkgo biloba extract reveal powerful effects in reducing most ALI phenotypes, including inflammatory infiltrate, vascular permeability, and edema. As outlined in this review, we propose that there are several extracts of plants and compounds isolated from them with anti-inflammatory effects in ALI. So, they demonstrate potential to be used in the preliminary testing in humans which can provide a new alternative for ALI therapy.

\section{Abbreviations}

ALI: Acute lung injury

ARDS: Acute respiratory distress syndrome

BALF: Bronchoalveolar lavage fluids

CCL: Chemokine (C-C motif) ligand

COX-2: Cyclooxygenase-2

CXCL: Chemokine (C-X-C motif) ligand

EGb: Ginkgo biloba extract

$\mathrm{HCl}$ Hydrochloric acid

IL: Interleukin

LPS: Lipopolysaccharide

MAPK: Mitogen-activated protein (MAP) kinase

MPO: Myeloperoxidase

NF- $\kappa$ B: Nuclear factor-kappa B

TNF- $\alpha$ : Tumor necrosis factor-alpha

SOD: Superoxide dismutase

MDA: Malondialdehyde

TBX: Thromboxane

ROS: Reactive oxygen species

ERK: Kinase activated by extracellular signal

MIP: Macrophage inflammatory protein

MMP: Matrix metalloprotease

GR: Glucocorticoid receptor

iNOS: Inducible nitric oxide synthase

PMN: Polymorphonuclear.

\section{Acknowledgments}

This work was supported by Grants from the Conselho Nacional de Desenvolvimento Científico e Tecnológico (CNPq) (no. 475349/2010-5), Fundação de Apoio a Pesquisa do Estado de Minas Gerais (FAPEMIG; no. 01/11 CDS APQ 01631/11), Rede de Pesquisa em Doenças Infecciosas Humanas e Animais do Estado de Minas Gerais (code REDE 20/12), Fundação de Ensino e Pesquisa de Uberaba (FUNEPU; no. 03/2009), and Universidade Federal do Triângulo Mineiro (UFTM) (Brazil).

\section{References}

[1] D. G. Ashbaugh, D. B. Bigelow, T. L. Petty, and B. E. Levine, "Acute respiratory distress in adults," The Lancet, vol. 2, no. 7511, pp. 319-323, 1967.

[2] N. D. Eves, Y. Song, A. A. Piper, and T. M. Maher, "Year in review 2012: acute lung injury, interstitial lung diseases, sleep and physiology," Respirology, vol. 18, no. 3, pp. 555-573, 2013.

[3] M. Donahoe, "Acute respiratory distress syndrome: a clinical review," Pulmonary Circulation, vol. 1, pp. 192-211, 2011.
[4] R. Randhawa and G. Bellingan, "Acute lung injury," Anaesthesia and Intensive Care Medicine, vol. 8, no. 11, pp. 477-480, 2007.

[5] M. D. Zilberberg and S. K. Epstein, "Acute lung injury in the medical ICU-comorbid conditions, age, etiology, and hospital outcome," American Journal of Respiratory and Critical Care Medicine, vol. 157, no. 4, pp. 1159-1164, 1998.

[6] V. M. Ranieri, G. D. Rubenfeld, B. T. Thompson et al., "Acute respiratory distress syndrome: the Berlin definition," Journal of the American Medical Association, vol. 20, pp. 2526-2533, 2012.

[7] G. R. Bernard, A. Artigas, K. L. Brigham et al., "The AmericanEuropean Consensus Conference on ARDS: definitions, mechanisms, relevant outcomes, and clinical trial coordination," American Journal of Respiratory and Critical Care Medicine, vol. 149, no. 3, pp. 818-824, 1994.

[8] T. Zhu, W. Zhang, and D.-X. Wang, "Insulin up-regulates epithelial sodium channel in LPS-induced acute lung injury model in rats by SGK1 activation," Injury, vol. 8, pp. 1277-1250, 2012.

[9] J. J. Hofstra, A. D. Cornet, P. J. Declerck et al., "Nebulized fibrinolytic agents improve pulmonary fibrinolysis but not inflammation in rat models of direct and indirect acute lung injury," PLoS ONE, vol. 8, pp. 552-562, 2013.

[10] V. von Dossow-Hanfstingl, "Advances in therapy for acute lung injury," Anesthesiology Clinics, vol. 30, pp. 629-639, 2012.

[11] X. Fang, C. Bai, and X. Wang, "Bioinformatics insights into acute lung injury/acute respiratory distress syndrome," Clinical and Translational Medicine, vol. 1, article 9, 2012.

[12] M. A. Matthay, L. B. Ware, and G. A. Zimmerman, "The acute respiratory distress syndrome," The Journal of Clinical Investigation, vol. 122, pp. 2731-2740, 2012.

[13] A. J. Walkey, R. Summer, V. Ho, and P. Alkana, "Acute respiratory distress syndrome: epidemiology and management approaches," Journal of Clinical Epidemiology, vol. 4, pp. 159169, 2012.

[14] A. MacKay and M. Al-Haddad, "Acute lung injury," Anaesthesia and Intensive Care Medicine, vol. 11, no. 11, pp. 487-489, 2010.

[15] E. R. Johnson and M. A. Matthay, "Acute lung injury: epidemiology, pathogenesis, and treatment," Journal of Aerosol Medicine and Pulmonary Drug Delivery, vol. 23, no. 4, pp. 243-252, 2010.

[16] M. R. Wilson and M. Takata, "Inflammatory mechanisms of ventilator-induced lung injury: a time to stop and think?" Anaesthesia, vol. 68, pp. 175-178, 2013.

[17] S. Zhang, S. D. Danchuk, K. M. Imhof et al., "Comparison of the therapeutic effects of human and mouse adipose- derived stem cells in a murine model of lipopolysaccharide-induced acute lung injury," Stem Cell Research \& Therapy, vol. 4, pp. 13-20, 2013.

[18] X. Y. Chen, S. M. Wang, N. Li et al., "Creation of lung-targeted dexamethasone immunoliposome and its therapeutic effect on bleomycin-induced lung injury in rats," PLoS ONE, vol. 8, pp. 58-75, 2013.

[19] Y. L. Xu, Y. L. Liu, Q. Wang, G. Li, X. D. Lü, and B. Kong, "Intravenous transplantation of mesenchymal stem cells attenuates oleic acid induced acute lung injury in rats," Chinese Medical Journal, vol. 8, pp. 125-136, 2012.

[20] A. T. Reddy, S. P. Lakshmi, and R. C. Reddy, "The nitrated fatty acid 10-nitro-oleate diminishes severity of LPS-induced acute lung injury in mice," PPAR Research, vol. 2012, Article ID 617063, 12 pages, 2012.

[21] J. Grommes, S. Vijayan, M. Drechsler et al., "Simvastatin reduces endotoxin-induced acute lung," PLoS ONE, vol. 7, Article ID e38917, 2012. 
[22] H. Inoue, Y. Nakagawa, M. Ikemura, E. Usugi, and M. Nata, "Molecular-biological analysis of acute lung injury (ALI) induced by heat exposure and/or intravenous administration of oleic acid," Legal Medicine, vol. 6, pp. 304-312, 2012.

[23] G. Matute-Bello, C. W. Frevert, and T. R. Martin, "Animal models of acute lung injury," American Journal of PhysiologyLung Cellular and Molecular Physiology, vol. 295, no. 3, pp. L379-L399, 2008.

[24] H. Ehrentraut, E. T. Clambey, E. N. McNamee et al., "CD73 ${ }^{+}$ regulatory $\mathrm{T}$ cells contribute to adenosine-mediated resolution of acute lung injury," The FASEB Journal, vol. 27, no. 6, pp. 22072219, 2013.

[25] M. Bhargava and C. H. Wendt, "Biomarkers in acute lung injury," Translational Research, vol. 159, no. 4, pp. 205-217, 2012.

[26] D. El Kebir, P. Gjorstrup, and J. G. Filep, "Resolvin E1 promotes phagocytosis-induced neutrophil apoptosis and accelerates resolution of pulmonary inflammation," Proceedings of the National Academy of Sciences of the United States of America, vol. 109, no. 37, pp. 14983-14988, 2012.

[27] R. P. Baughman, K. L. Gunther, M. C. Rashkin, D. A. Keeton, and E. N. Pattishall, "Changes in the inflammatory response of the lung during acute respiratory distress syndrome: prognostic indicators," American Journal of Respiratory and Critical Care Medicine, vol. 154, no. 1, pp. 76-81, 1996.

[28] S. Matsuo, W. L. Yang, M. Aziz, A. Jacob, and P. Wang, "Cyclic arginine-glycine-aspartate attenuates acute lung injury in mice after intestinal ischemia/reperfusion," The Journal of Critical Care, vol. 17, pp. 5-19, 2013.

[29] J. Grommes and O. Soehnlein, "Contribution of neutrophils to acute lung injury," Molecular Medicine, vol. 17, no. 3-4, pp. 293307, 2011.

[30] M. A. Freudenberg, S. Tchaptchet, S. Keck et al., "Lipopolysaccharide sensing an important factor in the innate immune response to Gram-negative bacterial infections: benefits and hazards of LPS hypersensitivity," Immunobiology, vol. 213, no. 3-4, pp. 193-203, 2008.

[31] L. Liaudet, P. Á. L. Pacher, J. G. Mabley et al., "Activation of poly(ADP-ribose) polymerase- 1 is a central mechanism of lipopolysaccharide-induced acute lung inflammation," American Journal of Respiratory and Critical Care Medicine, vol. 165, no. 3, pp. 372-377, 2002.

[32] H.-X. Li, J.-C. Zhang, Y.-L. Zhao, and H.-J. Hao, "Effects of interleukin-10 on expression of inflammatory mediators and antiinflammatory mediators during acute lung injury in rats," Zhongguo Wei Zhong Bing Ji Jiu Yi Xue, vol. 17, no. 6, pp. 338-341, 2005.

[33] A. B. Lentsch, B. J. Czermak, J. A. Jordan, and P. A. Ward, "Regulation of acute lung inflammatory injury by endogenous IL-13," Journal of Immunology, vol. 162, no. 2, pp. 1071-1076, 1999.

[34] J. Corne, G. Chupp, C. G. Lee et al., "IL-13 stimulates vascular endothelial cell growth factor and protects against hyperoxic acute lung injury," The Journal of Clinical Investigation, vol. 106, no. 6, pp. 783-791, 2000.

[35] A. Ortega-Gómez, M. Perretti, and O. Soehnlein, "Resolution of inflammation: an integrated view," EMBO Molecular Medicine, vol. 5, no. 5, pp. 661-674, 2013.

[36] D. El Kebir and J. G. Filep, "Modulation of neutrophil apoptosis and the resolution of inflammation through $\beta 2$ integrins," Frontiers in Immunology, vol. 4, article 60, 2013.

[37] S. Krishnamoorthy, A. Recchiuti, N. Chiang et al., "Resolvin D1 binds human phagocytes with evidence for proresolving receptors," Proceedings of the National Academy of Sciences of the United States of America, vol. 107, no. 4, pp. 1660-1665, 2010.

[38] C. N. Serhan, S. D. Brain, C. D. Buckley et al., "Resolution of inflammation: state of the art, definitions and terms," The FASEB Journal, vol. 21, no. 2, pp. 325-332, 2007.

[39] B. D. Levy, G. T. de Sanctis, P. R. Devchand et al., "Multi-pronged inhibition of airway hyper-responsiveness and inflammation by lipoxin A4," Nature Medicine, vol. 8, no. 9, pp. 1018-1023, 2002.

[40] C. N. Serhan, S. Hong, K. Gronert et al., "Resolvins: a family of bioactive products of omega-3 fatty acid transformation circuits initiated by aspirin treatment that counter proinflammation signals," Journal of Experimental Medicine, vol. 196, no. 8, pp. 1025-1037, 2002.

[41] M. Cepkova and M. A. Matthay, "Pharmacotherapy of acute lung injury and the acute respiratory distress syndrome," Journal of Intensive Care Medicine, vol. 21, no. 3, pp. 119-143, 2006.

[42] C. M. Yamashita and J. F. Lewis, "Emerging therapies for treatment of acute lung injury and acute respiratory distress syndrome," Expert Opinion on Emerging Drugs, vol. 17, no. 1, pp. $1-4,2012$.

[43] K. Fukunaga, P. Kohli, C. Bonnans, L. E. Fredenburgh, and B. D. Levy, "Cyclooxygenase 2 plays a pivotal role in the resolution of acute lung injury," Journal of Immunology, vol. 174, no. 8, pp. 5033-5039, 2005.

[44] G. Matute-Bello, C. W. Frevert, O. Kajikawa et al., "Septic shock and acute lung injury in rabbits with peritonitis: failure of the neutrophil response to localized infection," American Journal of Respiratory and Critical Care Medicine, vol. 163, no. 1, pp. 234243, 2001.

[45] W. D. Hardie, D. R. Prows, G. D. Leikauf, and T. R. Korfhagen, "Attenuation of acute lung injury in transgenic mice expressing human transforming growth factor- $\alpha$," American Journal of Physiology-Lung Cellular and Molecular Physiology, vol. 277, no. 5, pp. L1045-L1050, 1999.

[46] Y. Song, N. Fukuda, C. Bai, T. Ma, M. A. Matthay, and A. S. Verkman, "Role of aquaporins in alveolar fluid clearance in neonatal and adult lung, and in oedema formation following acute lung injury: studies in transgenic aquaporin null mice," Journal of Physiology, vol. 525, no. 3, pp. 771-779, 2000.

[47] L. Hsu, T. McDermott, L. Brown, and S. M. Aguayo, "Transgenic HbS mouse neutrophils in increased susceptibility to acute lung injury: implications for sickle acute chest syndrome," Chest, vol. 116, no. 1, supplement, p. 92S, 1999.

[48] L. Hsu, T. McDermott, Y. Gu, L. S. Brown, and S. M. Aguayo, "Transgenic mice neutrophils in increased susceptibility to acute lung injury- implications for sickle acute chest syndrome," Pediatric Research, vol. 43, p. 133, 1998.

[49] C. C. dos Santos, D. Okutani, P. Hu et al., "Differential gene profiling in acute lung injury identifies injury-specific gene expression," Critical Care Medicine, vol. 36, no. 3, pp. 855-865, 2008.

[50] S. C. Wesselkamper, D. R. Prows, P. Biswas, K. Willeke, E. Bingham, and G. D. Leikauf, "Genetic susceptibility to irritantinduced acute lung injury in mice," American Journal of Physiology-Lung Cellular and Molecular Physiology, vol. 279, no. 3, pp. L575-L582, 2000.

[51] A. Y. Meliton, N. M. Muñoz, L. N. Meliton, A. A. Birukova, A. R. Leff, and K. G. Birukov, "Mechanical induction of group $\mathrm{V}$ phospholipase $\mathrm{A}_{2}$ causes lung inflammation and acute lung injury," American Journal of Physiology-Lung Cellular and Molecular, vol. 304, no. 10, pp. L689-L700, 2013. 
[52] X. Huang and Y. Y. Zhao, "Transgenic expression of FoxM1 promotes endothelial repair following lung injury induced by polymicrobial sepsis in mice," PLoS ONE, vol. 7, article 11, 2012.

[53] J. E. Levitt and M. A. Matthay, "Clinical review: early treatment of acute lung injury-paradigm shift toward prevention and treatment prior to respiratory failure," Critical Care, vol. 16, p. 223, 2012.

[54] S. Tasaka, N. Hasegawa, and A. Ishizaka, "Pharmacology of acute lung injury," Pulmonary Pharmacology and Therapeutics, vol. 15, no. 2, pp. 83-95, 2002.

[55] J. B. Calixto, A. Beirith, J. Ferreira, A. R. Santos, V. C. Filho, and R. A. Yunes, "Naturally occurring antinociceptive substances from plants," Phytotherapy Research, vol. 14, pp. 401-418, 2000.

[56] J. B. Calixto, M. M. Campos, M. F. Otuki, and A. R. S. Santos, "Anti-inflammatory compounds of plant origin-part II: modulation of pro-inflammatory cytokines, chemokines and adhesion molecules," Planta Medica, vol. 70, no. 2, pp. 93-103, 2004.

[57] R. Verpoorte, "Exploration of nature's chemodiversity: the role of secondary metabolites as leads in drug development," Drug Discovery Today, vol. 3, no. 5, pp. 232-238, 1998.

[58] G. Seelinger, I. Merfort, and C. M. Schempp, "Anti-oxidant, anti-inflammatory and anti-allergic activities of luteolin," Planta Medica, vol. 74, no. 14, pp. 1667-1677, 2008.

[59] T. Zhu, D. X. Wang, W. Zhang et al., "Andrographolide protects against LPS-induced acute lung injury by inactivation of NF«B," PLoS ONE, vol. 8, 2013.

[60] D. C. Favarin, M. M. Teixeira, E. L. Andrade et al., "Anti-inflammatory effects of ellagic acid on acute lung injury induced by acid in mice," Mediators of Inflammation, vol. 2013, Article ID 164202, 13 pages, 2013.

[61] A. P. Rogerio, C. Fontanari, M. C. C. Melo et al., "Anti-inflammatory, analgesic and anti-oedematous effects of Lafoensia pacari extract and ellagic acid," Journal of Pharmacy and Pharmacology, vol. 58, no. 9, pp. 1265-1273, 2006.

[62] A. P. Rogerio, A. Sá-Nunes, and L. H. Faccioli, "The activity of medicinal plants and secondary metabolites on eosinophilic inflammation," Pharmacological Research, vol. 62, no. 4, pp. 298-307, 2010.

[63] H.-B. Bae, M. Li, J.-P. Kim et al., “The effect of epigallocatechin gallate on lipopolysaccharide-induced acute lung injury in a murine model," Inflammation, vol. 33, no. 2, pp. 82-91, 2010.

[64] K. J. Xu, S. F. Zhang, and Q. X. Li, "Preventive and treatment effect of composite Rhodiolae on acute lung injury in patients with severe pulmonary hypertension during extracorporeal circulation," Zhongguo Zhong Xi Yi Jie He Za Zhi, vol. 23, pp. 648-650, 2003.

[65] C. Zhang, C. Ren, H. Chen et al., "The analog of Ginkgo biloba extract 761 is a protective factor of cognitive impairment induced by chronic fluorosis," Biological Trace Element Research, vol. 153, no. 1-3, pp. 229-236, 2013.

[66] F. Qiu, J. B. Friesen, J. B. McAlpine, and G. F. Pauli, "Design of countercurrent separation of Ginkgo biloba terpene lactones by nuclear magnetic resonance," Journal of Chromatography A, vol. 1242, pp. 26-34, 2012.

[67] S. Jaracz, K. Strømgaard, and K. Nakanishi, "Ginkgolides: selective acetylations, translactonization, and biological evaluation," Journal of Organic Chemistry, vol. 67, no. 13, pp. 4623-4626, 2002.

[68] A. S. El-Khatib, A. M. Moustafa, A.-A. H. Abdel-Aziz, O. A. AlShabanah, and H. A. El-Kashef, "Ginkgo biloba extract (EGb 761) modulates bleomycin-induced acute lung injury in rats," Tumori, vol. 87, no. 6, pp. 417-422, 2001.
[69] R. Sun, H. Zhang, Q. Si, and S. Wang, "Protective effect of Ginkgo biloba extract on acute lung injury induced by lipopolysaccharide in D-galactose aging rats," Zhonghua Jie He He Hu Xi Za Zhi, vol. 25, no. 6, pp. 352-355, 2002.

[70] C. F. Gonçalves-de-Albuquerque, A. R. Silva, P. Burth et al., "Oleic acid induces lung injury in mice through activation of the ERK pathway," Mediators of Inflammation, vol. 2012, Article ID 956509, 11 pages, 2012.

[71] S. Solon, L. Lopes, P. Teixeira de Sousa Jr., and G. SchmedaHirschmann, "Free radical scavenging activity of Lafoensia pacari," Journal of Ethnopharmacology, vol. 72, no. 1-2, pp. 173$178,2000$.

[72] V. da Mota Menezes, Á. N. Atallah, A. J. Lapa, and W. R. Catapani, "Assessing the therapeutic use of Lafoensia pacari St. Hil. extract (mangava-brava) in the eradication of Helicobacter pylori: double-blind randomized clinical trial," Helicobacter, vol. 11, no. 3, pp. 188-195, 2006.

[73] A. P. Rogerio, C. Fontanari, É. Borducchi et al., "Antiinflammatory effects of Lafoensia pacari and ellagic acid in a murine model of asthma," European Journal of Pharmacology, vol. 580, no. 1-2, pp. 262-270, 2008.

[74] A. P. Rogerio, A. Sá-Nunes, D. A. Albuquerque et al., "Lafoensia pacari extract inhibits IL-5 production in toxocariasis," Parasite Immunology, vol. 25, no. 7, pp. 393-400, 2003.

[75] A. I. Medeiros, C. L. Silva, A. Malheiro, C. M. L. Maffei, and L. H. Faccioli, "Leukotrienes are involved in leukocyte recruitment induced by live Histoplasma capsulatum or by the $\beta$-glucan present in their cell wall," British Journal of Pharmacology, vol. 128, no. 7, pp. 1529-1537, 1999.

[76] R. Bachoual, W. Talmoudi, T. Boussetta, F. Braut, and J. ElBenna, "An aqueous pomegranate peel extract inhibits neutrophil myeloperoxidase in vitro and attenuates lung inflammation in mice," Food and Chemical Toxicology, vol. 49, no. 6, pp. 1224-1228, 2011.

[77] E. Middleton Jr., C. Kandaswami, and T. C. Theoharides, "The effects of plant flavonoids on mammalian cells: implications for inflammation, heart disease, and cancer," Pharmacological Reviews, vol. 52, no. 4, pp. 673-751, 2000.

[78] R. J. Nijveldt, E. van Nood, D. E. C. van Hoorn, P. G. Boelens, K. van Norren, and P. A. M. van Leeuwen, "Flavonoids: a review of probable mechanisms of action and potential applications," American Journal of Clinical Nutrition, vol. 74, no. 4, pp. 418425, 2001.

[79] M. K. Chahar, N. Sharma, M. P. Dobhal, and Y. C. Joshi, "Flavonoids: a versatile source of anticancer drugs," Pharmacognosy Reviews, vol. 5, no. 9, pp. 1-12, 2011.

[80] P.-G. Pietta, "Flavonoids as antioxidants," Journal of Natural Products, vol. 63, no. 7, pp. 1035-1042, 2000.

[81] M. Serafini, I. Peluso, and A. Raguzzini, "Flavonoids as antiinflammatory agents," Proceedings of the Nutrition Society, vol. 69, no. 3, pp. 273-278, 2010.

[82] M. Kawai, T. Hirano, S. Higa et al., "Flavonoids and related compounds as anti-allergic substances," Allergology International, vol. 56, no. 2, pp. 113-123, 2007.

[83] H. Si, R. P. Wyeth, and D. Liu, "The flavonoid luteolin induces nitric oxide production and arterial relaxation," European Journal of Nutrition, 2013.

[84] Y.-C. Li, C.-H. Yeh, M.-L. Yang, and Y.-H. Kuan, "Luteolin suppresses inflammatory mediator expression by blocking the $\mathrm{Akt} / \mathrm{NF} \kappa \mathrm{B}$ pathway in acute lung injury induced by lipopolysaccharide in mice," Evidence-Based Complementary and Alternative Medicine, vol. 2012, Article ID 383608, 8 pages, 2012. 
[85] M.-Y. Kuo, M.-F. Liao, F.-L. Chen et al., "Luteolin attenuates the pulmonary inflammatory response involves abilities of antioxidation and inhibition of MAPK and NF $\kappa$ B pathways in mice with endotoxin-induced acute lung injury," Food and Chemical Toxicology, vol. 49, no. 10, pp. 2660-2666, 2011.

[86] J.-P. Lee, Y.-C. Li, H.-Y. Chen et al., "Protective effects of luteolin against lipopolysaccharide-induced acute lung injury involves inhibition of MEK/ERK and PI3K/Akt pathways in neutrophils," Acta Pharmacologica Sinica, vol. 31, no. 7, pp. 831838, 2010.

[87] G.-L. Xu, L. Yao, S.-Q. Yu et al., "Effect of epigallocatechingallate on acute lung injury induced by oleic acid in mice," Yao Xue Xue Bao, vol. 40, no. 3, pp. 231-235, 2005.

[88] H. A. Vogel and J. Pelletier, "Curcumin biological and medicinal properties," Journal of Pharmacology, vol. 2, p. 50, 1815.

[89] Y. Henrotin, F. Priem, and A. Mobasheri, "Curcumin: a new paradigm and therapeutic opportunity for the treatment of osteoarthritis: curcumin for osteoarthritis management," Springerplus, vol. 56, p. 56, 2013.

[90] G. Grynkiewicz and P. Ślifirski, "Curcumin and curcuminoids in quest for medicinal status," Acta Biochimica Polonica, vol. 2, pp. 201-213, 2012.

[91] I. M. Leitman, "Curcumin for the prevention of acute lung injury in sepsis: is it more than the flavor of the month?" Journal of Surgical Research, vol. 176, pp. 5-7, 2012.

[92] S. C. Gupta, S. Patchva, W. Koh, and B. B. Aggarwal, "Discovery of curcumin, a component of golden spice, and its miraculous biological activities," Clinical and Experimental Pharmacology and Physiology, vol. 39, no. 3, pp. 283-299, 2012.

[93] F. Xu, S. H. Lin, Y. Z. Yang, R. Guo, J. Cao, and Q. Liu, “The effect of curcumin on sepsis-induced acute lung injury in a rat model through the inhibition of the TGF- $\beta 1 /$ SMAD3 pathway," International Immunopharmacology, vol. 16, pp. 1-6, 2013.

[94] X. Xiao, M. Yang, D. Sun, and S. Sun, "Curcumin protects against sepsis-induced acute lung injury in rats," Journal of Surgical Research, vol. 1, pp. 31-40, 2012.

[95] M. Gunaydın, A. Guzel, A. Guzel et al., "The effect of curcumin on lung injuries in a rat model induced by aspirating gastrointestinal decontamination agents," Journal of Surgical Research, vol. 9, pp. 1669-1746, 2012.

[96] A. Guzel, M. Kanter, A. Guzel, A. F. Yucel, and M. Erboga, "Protective effect of curcumin on acute lung injury induced by intestinal ischemia/reperfusion," Toxicology \& Industrial Health, vol. 29, no. 7, pp. 633-642, 2013.

[97] M. R. Smith, S. R. Gangireddy, V. R. Narala et al., "Curcumin inhibits fibrosis-related effects in IPF fibroblasts and in mice following bleomycin-induced lung injury," American Journal of Physiology_Lung Cellular and Molecular Physiology, vol. 298, no. 5, pp. L616-L625, 2010.

[98] S. Bansal and S. Chhibber, "Curcumin alone and in combination with augmentin protects against pulmonary inflammation and acute lung injury generated during Klebsiella pneumoniae B5055-induced lung infection in BALB/c mice," Journal of Medical Microbiology, vol. 59, no. 4, pp. 429-437, 2010.

[99] R.-F. Zhu, M. Zhou, J.-L. He, F.-Y. Ding, S.-Q. Yu, and G.-L. $\mathrm{Xu}$, "Protective effect of curcumine on oleic-induced acute lung injury in rats," Zhongguo Zhong Yao Za Zhi, vol. 33, no. 17, pp. 2141-2145, 2008.

[100] Q. Lian, X. Li, Y. Shang, S. Yao, L. Ma, and S. Jin, "Protective effect of curcumin on endotoxin-induced acute lung injury in rats," Journal of Huazhong University of Science and Technology, vol. 6, pp. 678-759, 2006.
[101] P. J. Barnes, “Theophylline: new perspectives for an old drug," American Journal of Respiratory and Critical Care Medicine, vol. 167, no. 6, pp. 813-818, 2003.

[102] C. Guillot, M. Fornaris, M. Badier, and J. Orehek, "Spontaneous and provoked resistance to isoproterenol in isolated human bronchi," Journal of Allergy and Clinical Immunology, vol. 74, no. 5, pp. 713-718, 1984.

[103] Y. Kaneko, K. Takashima, N. Suzuki, and K. Yamana, "Effects of theophylline on chronic inflammatory lung injury induced by LPS exposure in guinea pigs," Allergology International, vol. 56, no. 4, pp. 445-456, 2007.

[104] L. R. Fortunato, C. F. Alves, M. M. Teixeira, and A. P. Rogerio, "Quercetin: a flavonoid with the potential to treat asthma," Brazilian Journal of Pharmaceutical Sciences, vol. 48, pp. 589599, 2012.

[105] T. Ohrui, M. Yamaya, T. Suzuki et al., "Mechanisms of gastric juice-induced hyperpermeability of the cultured human tracheal epithelium," Chest, vol. 111, no. 2, pp. 454-459, 1997.

[106] K. Hayashida, S. Fujishima, K. Sasao et al., "Early administration of sivelestat, the neutrophil elastase inhibitor, in adults for acute lung injury following gastric aspiration," Shock, vol. 36, no. 3, pp. 223-227, 2011.

[107] B. A. Davidson, R. R. Vethanayagam, M. J. Grimm et al., "NADPH oxidase and Nrf2 regulate gastric aspiration-induced inflammation and acute lung injury," Journal of Immunology, vol. 190, pp. 1714-1738, 2013.

[108] H. Dang, S. Wang, L. Yang, F. Fang, and F. Xu, "Upregulation of Shh and Ptcl in hyperoxia-induced acute lung injury in neonatal rats," Molecular Medicine Reports, vol. 6, pp. 297-302, 2012.

[109] B. V. Patel, M. R. Wilson, and M. Takata, "Resolution of acute lung injury and inflammation: a translational mouse model," European Respiratory Journal, vol. 39, no. 5, pp. 1162-1170, 2012.

[110] K. Modelska, J.-F. Pittet, H. G. Folkesson, V. C. Broaddus, and M. A. Matthay, "Acid-induced lung injury: protective effect of anti-interleukin-8 pretreatment on alveolar epithelial barrier function in rabbits," American Journal of Respiratory and Critical Care Medicine, vol. 160, no. 5, pp. 1450-1456, 1999.

[111] J. W. Kuiper, F. B. Plötz, A. J. Groeneveld et al., "High tidal volume mechanical ventilation-induced lung injury in rats is greater after acid instillation than after sepsis-induced acute lung injury, but does not increase systemic inflammation: an experimental study," BMC Anesthesiology, vol. 11, article 26, 2011.

[112] H. Goto, J. G. Ledford, S. Mukherjee, P. W. Noble, K. L. Williams, and J. R. Wright, "The role of surfactant protein A in bleomycininduced acute lung injury," American Journal of Respiratory and Critical Care Medicine, vol. 181, no. 12, pp. 1336-1344, 2010.

[113] Y. Zhou, D. J. Schneider, E. Morschl et al., "Distinct roles for the $\mathrm{A} 2 \mathrm{~B}$ adenosine receptor in acute and chronic stages of bleomycin-induced lung injury," Journal of Immunology, vol. 186, no. 2, pp. 1097-1106, 2011.

[114] B. B. Moore and C. M. Hogaboam, "Murine models of pulmonary fibrosis," American Journal of Physiology - Lung Cellular and Molecular Physiology, vol. 294, no. 2, pp. L152-L160, 2008.

[115] H. Guo, F. Ji, B. Liu, X. Chen, J. He, and J. Gong, "Peiminine ameliorates bleomycin-induced acute lung injury in rats," Molecular Medicine Reports, vol. 7, pp. 1103-1113, 2013.

[116] F. Venet, X. Huang, C.-S. Chung, Y. Chen, and A. Ayala, "Plasmacytoid dendritic cells control lung inflammation and monocyte recruitment in indirect acute lung injury in mice," American Journal of Pathology, vol. 176, no. 2, pp. 764-773, 2010. 
[117] D. Fei, X. Meng, K. Kang et al., "Heme oxygenase-1 modulates thrombomodulin and activated protein $c$ levels to attenuate lung injury in cecal ligation and punctureinduced acute lung injury mice," Experimental Lung Research, vol. 38, no. 4, pp. 173$182,2012$.

[118] L. Xu, H. G. Bao, Y. N. Si et al., "Effects of adiponectin on acute lung injury in cecal ligation and puncture-induced sepsis rats," Journal of Surgical Research, vol. 13, 2013.

[119] J. Villar, S. P. Ribeiro, J. B. M. Mullen, M. Kuliszewski, M. Post, and A. S. Slutsky, "Induction of the heat shock response reduces mortality rate and organ damage in a sepsis-induced acute lung injury model," Critical Care Medicine, vol. 22, no. 6, pp. 914-921, 1994.

[120] Q. Pang, L. Dou, X. Pan et al., "Methylene chloride protects against cecal ligation and puncture-induced acute lung injury by modulating inflammatory mediators," International Immunopharmacology, vol. 10, no. 8, pp. 929-932, 2010.

[121] L. Frank, J. R. Bucher, and R. J. Roberts, "Oxygen toxicity in neonatal and adult animals of various species," Journal of Applied Physiology, vol. 45, no. 5, pp. 699-704, 1978.

[122] R. H. Kallet and M. A. Matthay, "Hyperoxic acute lung injury," Respiratory Care, vol. 58, pp. 123-164, 2013.

[123] K. Raghavendran, J. Nemzek, L. M. Napolitano, and P. R. Knight, "Aspiration-induced lung injury," Critical Care Medicine, vol. 39, no. 4, pp. 818-826, 2011.

[124] R. Howden, H.-Y. Cho, L. Miller-DeGraff et al., "Cardiac physiologic and genetic predictors of hyperoxia-induced acute lung injury in mice," American Journal of Respiratory Cell and Molecular Biology, vol. 46, no. 4, pp. 470-478, 2012.

[125] H. D. Li, Z. R. Zhang, Q. X. Zhang, Z. C. Qin, D. M. He, and J. S. Chen, "Treatment with exogenous hydrogen sulfide attenuates hyperoxia-induced acute lung injury in mice," European Journal of Applied Physiology, vol. 113, no. 6, pp. 1555-1563, 2013.

[126] J. H. Min, C. N. Codipilly, S. Nasim, E. J. Miller, and M. N. Ahmed, "Synergistic protection against hyperoxia-induced lung injury by neutrophils blockade and EC-SOD overexpression," Respiratory Research, vol. 20, pp. 13-58, 2012.

[127] N. M. Reddy, S. R. Kleeberger, T. W. Kensler, M. Yamamoto, P. M. Hassoun, and S. P. Reddy, "Disruption of Nrf2 impairs the resolution of hyperoxia-induced acute lung injury and inflammation in mice," Journal of Immunology, vol. 182, no. 11, pp. 7264-7271, 2009.

[128] Z. Tian, Y. Li, P. Ji, S. Zhao, and H. Cheng, "Mesenchymal stem cells protects hyperoxia-induced lung injury in newborn rats via inhibiting receptor for advanced glycation end-products/nuclear factor $\kappa \mathrm{B}$ signaling," Experimental Biology and Medicine, vol. 238, pp. 242-249, 2013.

[129] R. Fox-Dewhurst, M. K. Alberts, O. Kajikawa et al., "Pulmonary and systemic inflammatory responses in rabbits with gramnegative pneumonia," American Journal of Respiratory and Critical Care Medicine, vol. 155, no. 6, pp. 2030-2040, 1997.

[130] A. S. Cross, S. M. Opal, J. C. Sadoff, and P. Gemski, "Choice of bacteria in animal models of sepsis," Infection and Immunity, vol. 61, no. 7, pp. 2741-2747, 1993.

[131] L. R. Filgueiras Jr., J. O. Martins, C. H. Serezani, V. L. Capelozzi, M. B. Montes, and S. Jancar, "Sepsis-induced acute lung injury (ALI) is milder in diabetic rats and correlates with impaired NFkB activation," PLoS ONE, vol. 7, no. 9, Article ID e44987, 2012.

[132] R. G. Evans, O. B. Ndunge, and B. Naidu, "A novel two-hit rodent model of postoperative acute lung injury: priming the immune system leads to an exaggerated injury after pneumonectomy," Interactive CardioVascular and Thoracic Surgery, vol. 12, 2013.

[133] Z. Guo, Q. Li, Y. Han, Y. Liang, Z. Xu, and T. Ren, "Prevention of LPS-induced acute lung injury in mice by progranulin," Mediators of Inflammation, vol. 2012, Article ID 540794, 10 pages, 2012.

[134] Y. C. Hou, M. H. Pai, J. J. Liu, and S. L. Yeh, "Alanyl-glutamine resolves lipopolysaccharide-induced lung injury in mice by modulating the polarization of regulatory $\mathrm{T}$ cells and $\mathrm{T}$ helper 17 cells," Journal of Nutritional Biochemistry, vol. 24, no. 9, pp. 1555-1563, 2013.

[135] L. Ma, X. Y. Wu, L. H. Zhang et al., "Propofol exerts anti-inflammatory effects in rats with lipopolysaccharide-induced acute lung injury by inhibition of CD14 and TLR4 expression," Brazilian Journal of Medical and Biological Research, vol. 15, pp. $1-7,2013$.

[136] J. P. Wiener-Kronish, K. H. Albertine, and M. A. Matthay, "Differential responses of the endothelial and epithelial barriers of the lung in sheep to Escherichia coli endotoxin," The Journal of Clinical Investigation, vol. 88, no. 3, pp. 864-875, 1991.

[137] D.-F. Ben, X.-Y. Yu, G.-Y. Ji et al., “TLR4 mediates lung injury and inflammation in intestinal ischemia-reperfusion," Journal of Surgical Research, vol. 174, no. 2, pp. 326-333, 2012.

[138] K. Koike, F. A. Moore, E. E. Moore, R. S. Poggetti, R. M. Tuder, and A. Banerjee, "Endotoxin after gut ischemia/reperfusion causes irreversible lung injury," Journal of Surgical Research, vol. 52, no. 6, pp. 656-662, 1992.

[139] A. Guzel, M. Kanter, A. Guzel, A. Pergel, and M. Erboga, "Antiinflammatory and antioxidant effects of infliximab on acute lung injury in a rat model of intestinal ischemia/reperfusion," Journal of Molecular Histology, vol. 43, no. 3, pp. 361-369, 2012.

[140] D. P. Schuster, "ARDS: clinical lessons from the oleic acid model of acute lung injury," American Journal of Respiratory and Critical Care Medicine, vol. 149, no. 1, pp. 245-260, 1994.

[141] C. Hernández-Jiménez, J. R. Olmos-Zúñiga, R. Jasso-Victoria et al., "Effects of propofol pretreatment on endothelin in oleic acid-induced acute lung injury," Revista de Investigacion Clinica, vol. 64, pp. 452-512, 2012.

[142] Y. B. Zhu, Y. B. Zhang, D. H. Liu et al., "Atrial natriuretic peptide attenuates inflammatory responses on oleic acid-induced acute lung injury model in rats," Chinese Medical Journal, vol. 126, pp. 747-837, 2013.

[143] D. Tok, O. Ilkgul, S. Bengmark et al., "Pretreatment with proand synbiotics reduces peritonitis-induced acute lung injury in rats," Journal of Trauma, vol. 62, no. 4, pp. 880-885, 2007.

[144] C. Boland, V. Collet, E. Laterre, C. Lecuivre, X. Wittebole, and P.-F. Laterre, "Electrical vagus nerve stimulation and nicotine effects in peritonitis-induced acute lung injury in rats," Inflammation, vol. 34, no. 1, pp. 29-35, 2011.

[145] D. P. Mulloy, A. K. Sharma, L. G. Fernandez et al., "Adenosine $\mathrm{A}_{3}$ receptor activation attenuates lung ischemia-reperfusion injury," The Annals of Thoracic Surgery, vol. 28, pp. 4975-4988, 2013.

[146] T. Oyaizu, S.-Y. Fung, A. Shiozaki et al., "Src tyrosine kinase inhibition prevents pulmonary ischemia-reperfusion-induced acute lung injury," Intensive Care Medicine, vol. 38, no. 5, pp. 894-905, 2012.

[147] H. K. Yip, Y. C. Chang, C. G. Wallace et al., "Melatonin treatment improves adipose-derived mesenchymal stem cell therapy for acute lung ischemia-reperfusion injury," Journal of Pineal Research, vol. 54, pp. 207-228, 2013. 
[148] T. Sakuma, K. Takahashi, N. Ohya et al., "Ischemia-reperfusion lung injury in rabbits: mechanisms of injury and protection," American Journal of Physiology-Lung Cellular and Molecular Physiology, vol. 276, no. 1, pp. L137-L145, 1999.

[149] R. D. Novaes, R. V. Gonçalves, M. C. Cupertino et al., "Bark extract of Bathysa cuspidata attenuates extra-pulmonary acute lung injury induced by paraquat and reduces mortality in rats," International Journal of Experimental Pathology, vol. 93, pp. 225-258, 2012.

[150] C. H. Huang, M. L. Yang, C. H. Tsai, Y. C. Li, Y. J. Lin, and Y. H. Kuan, "Ginkgo biloba leaves extract (EGb 761) attenuates lipopolysaccharide-induced acute lung injury via inhibition of oxidative stress and NF- $\kappa \mathrm{B}$-dependent matrix metalloproteinase-9 pathway," Phytomedicine, vol. 20, pp. 303-312, 2013.

[151] L. Rong, Y. Chen, M. He, and X. Zhou, "Panax notoginseng saponins attenuate acute lung injury induced by intestinal ischaemia/reperfusion in rats," Respirology, vol. 14, no. 6, pp. 890898, 2009.

[152] C.-Q. Yang, Y. Ishitsuka, H. Moriuchi et al., "Protection afforded by a herbal medicine, Sho-seiryu-to (TJ-19), against oleic acidinduced acute lung injury in guinea-pigs," Journal of Pharmacy and Pharmacology, vol. 61, no. 7, pp. 925-932, 2009.

[153] W. Li, J. Y. Xie, H. Li et al., "Viola yedoensis liposoluble fraction ameliorates lipopolysaccharide-induced acute lung injury in mice," American Journal of Chinese Medicine, vol. 40, no. 5, pp. 1007-1025, 2012.

[154] C. R. Bezerra-Santos, A. Vieira-de-Abreu, G. C. Vieira et al., "Effectiveness of Cissampelos sympodialis and its isolated alkaloid warifteine in airway hyperreactivity and lung remodeling in a mouse model of asthma," International Immunopharmacology, vol. 13, no. 2, pp. 148-155, 2012.

[155] B. Zhang, Z.-Y. Liu, Y.-Y. Li et al., "Antiinflammatory effects of matrine in LPS-induced acute lung injury in mice," European Journal of Pharmaceutical Sciences, vol. 44, no. 5, pp. 573-579, 2011.

[156] J. Mabley, S. Gordon, and P. Pacher, "Nicotine exerts an antiinflammatory effect in a murine model of acute lung injury," Inflammation, vol. 34, no. 4, pp. 231-237, 2011.

[157] Y. F. Ni, F. Tian, Z. F. Lu et al., "Protective effect of nicotine on lipopolysaccharide-induced acute lung injury in mice," Respiration, vol. 81, no. 1, pp. 39-46, 2011.

[158] L. W. Soromou, N. Chen, L. Jiang et al., "Astragalin attenuates lipopolysaccharide-induced inflammatory responses by downregulating NF- $\kappa \mathrm{B}$ signaling pathway," Biochemical and Biophysical Research Communications, vol. 419, no. 2, pp. 256-261, 2012.

[159] P. Wang, X.-L. Ye, R. Liu et al., "Mechanism of acute lung injury due to phosgene exposition and its protection by cafeic acid phenethyl ester in the rat," Experimental and Toxicologic Pathology, vol. 65, pp. 311-319, 2013.

[160] Z. Wei, J. Yang, Y. F. Xia, W. Z. Huang, Z. T. Wang, and Y. Dai, "Cardamonin protects septic mice from acute lung injury by preventing endothelial barrier dysfunction," Journal of Biochemical and Molecular Toxicology, vol. 26, pp. 282-372, 2012.

[161] X. Chen, X. Yang, T. Liu et al., "Kaempferol regulates MAPKs and NF- $\kappa$ B signaling pathways to attenuate LPS-induced acute lung injury in mice," International Immunopharmacology, vol. 14, pp. 209-225, 2012.

[162] Y. Liu, H. Wu, Y.-C. Nie, J.-L. Chen, W.-W. Su, and P.-B. Li, "Naringin attenuates acute lung injury in LPS-treated mice by inhibiting NF- $\kappa \mathrm{B}$ pathway," International Immunopharmacology, vol. 11, no. 10, pp. 1606-1612, 2011.
[163] Y. Chen, Y. C. Nie, Y. L. Luo et al., "Protective effects of naringin against paraquat-induced acute lung injury and pulmonary fibrosis in mice," Food and Chemical Toxicology, vol. 58, pp. 133140, 2013.

[164] T. L. Tseng, M. F. Chen, M. J. Tsai, Y. H. Hsu, C. P. Chen, and T. J. Lee, "Oroxylin-A rescues LPS-induced acute lung injury via regulation of NF- $\kappa \mathrm{B}$ signaling pathway in rodents," PLOS ONE, vol. 7, Article ID e47403, 2012.

[165] L. Huang, J. Xianfei, and C. Cao, "Protective effects of quercetin in rats with lipopolysaccharide-induced acute lung injury," Chinese Journal of Emergency Medicine, vol. 13, no. 2, 2004.

[166] X. Yang, Q. Cai, J. He et al., "Geniposide, an iridoid glucoside derived from gardenia jasminoides, protects against lipopolysaccharide-induced acute lung injury in mice," Planta Medica, vol. 78, no. 6, pp. 557-564, 2012.

[167] X. Li, T. Xu, Q. Lian, B. Zeng, B. Zhang, and Y. Xie, "Protective effect of genistein on lipopolysaccharide-induced acute lung injury in rats," Journal of Huazhong University of Science and Technology. Medical Sciences, vol. 25, no. 4, pp. 454-457, 2005.

[168] J. L. Kang, H. W. Lee, H. S. Lee, I. S. Pack, V. Castranova, and Y. Koh, "Time course for inhibition of lipopolysaccharideinduced lung injury by genistein: relationship to alteration in nuclear factor- $\kappa \mathrm{B}$ activity and inflammatory agents," Critical Care Medicine, vol. 31, no. 2, pp. 517-524, 2003.

[169] M. V. Suresh, M. C. Wagner, G. R. Rosania et al., "Pulmonary administration of a water-soluble curcumin complex reduces severity of acute lung injury," American Journal of Respiratory Cell and Molecular Biology, vol. 47, pp. 280-287, 2012.

[170] W. Xin, L. Zhang, H. Fan, N. Jiang, T. Wang, and F. Fu, "Escin attenuates acute lung injury induced by endotoxin in mice," European Journal of Pharmaceutical Sciences, vol. 42, no. 1-2, pp. 73-80, 2011.

[171] Y.-F. Ni, J.-K. Kuai, Z.-F. Lu et al., "Glycyrrhizin treatment is associated with attenuation of lipopolysaccharide-induced acute lung injury by inhibiting cyclooxygenase- 2 and inducible nitric oxide synthase expression," Journal of Surgical Research, vol. 165, no. 1, pp. e29-e35, 2011.

[172] J.-R. Shi, L.-G. Mao, R.-A. Jiang, Y. Qian, H.-F. Tang, and J.-Q. Chen, "Monoammonium glycyrrhizinate inhibited the inflammation of LPS-induced acute lung injury in mice," International Immunopharmacology, vol. 10, no. 10, pp. 1235-1241, 2010.

[173] C.-Y. Sun, C.-Q. Pei, B.-X. Zang, L. Wang, and M. Jin, “The ability of hydroxysafflor yellow a to attenuate lipopolysaccharideinduced pulmonary inflammatory injury in mice," Phytotherapy Research, vol. 24, no. 12, pp. 1788-1795, 2010.

[174] X.-F. Wang, M. Jin, J. Tong, W. Wu, J.-R. Li, and B.-X. Zang, "Protective effect of hydroxysafflor yellow A against acute lung injury induced by oleic acid and lipopolysaccharide in rats," Yao Xue Xue Bao, vol. 45, no. 7, pp. 940-944, 2010. 


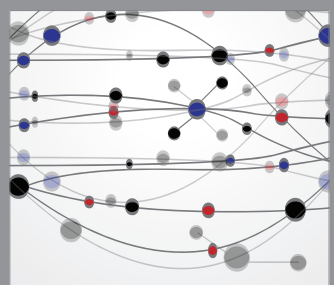

The Scientific World Journal
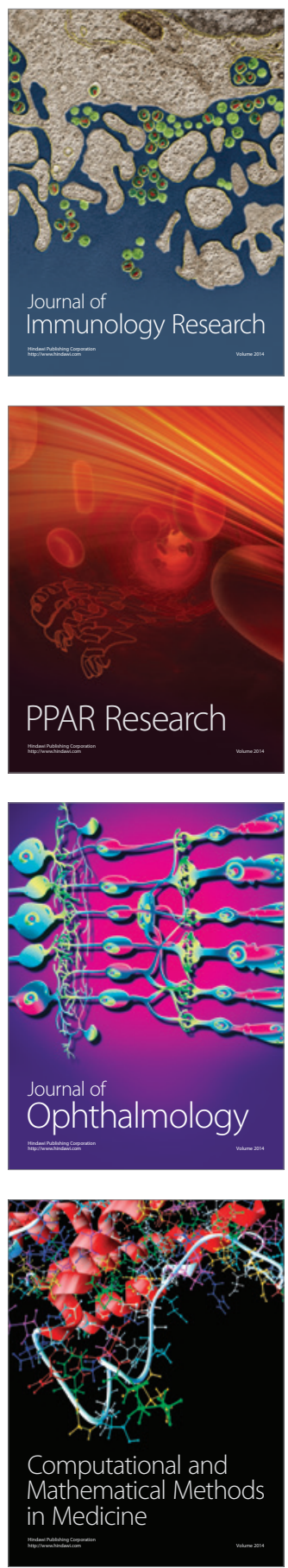

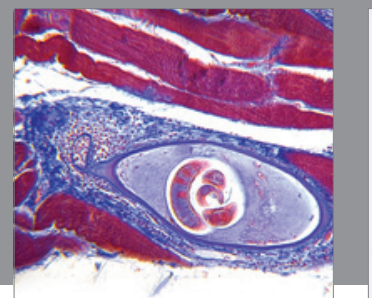

Gastroenterology

Research and Practice
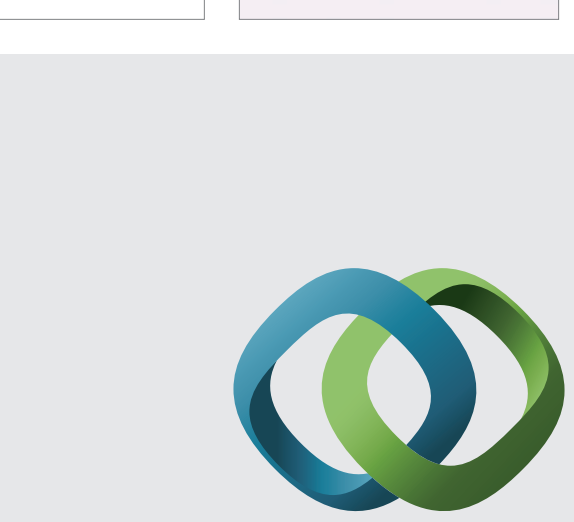

\section{Hindawi}

Submit your manuscripts at

http://www.hindawi.com
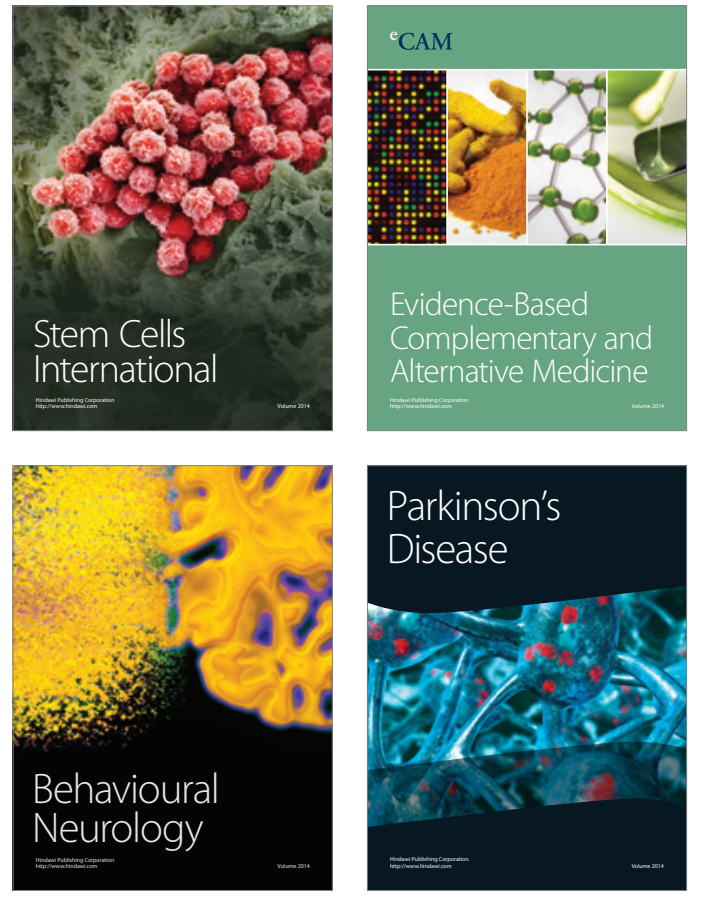
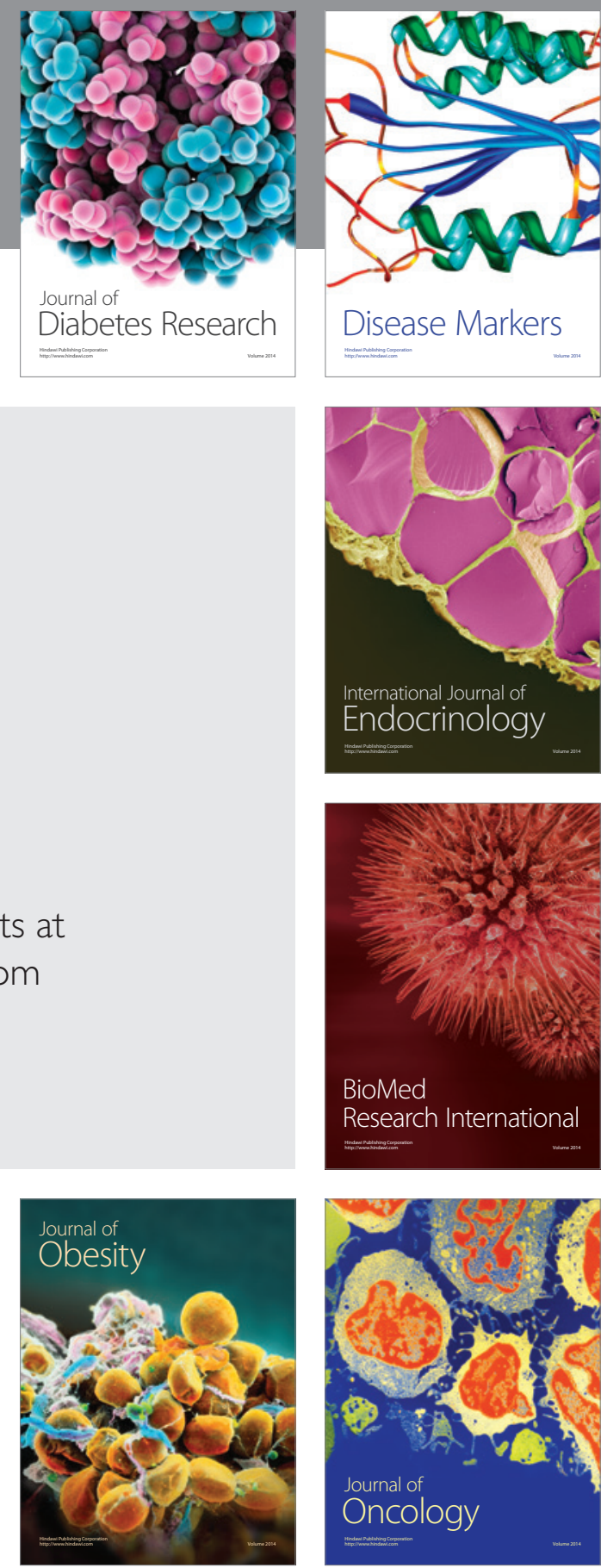

Disease Markers
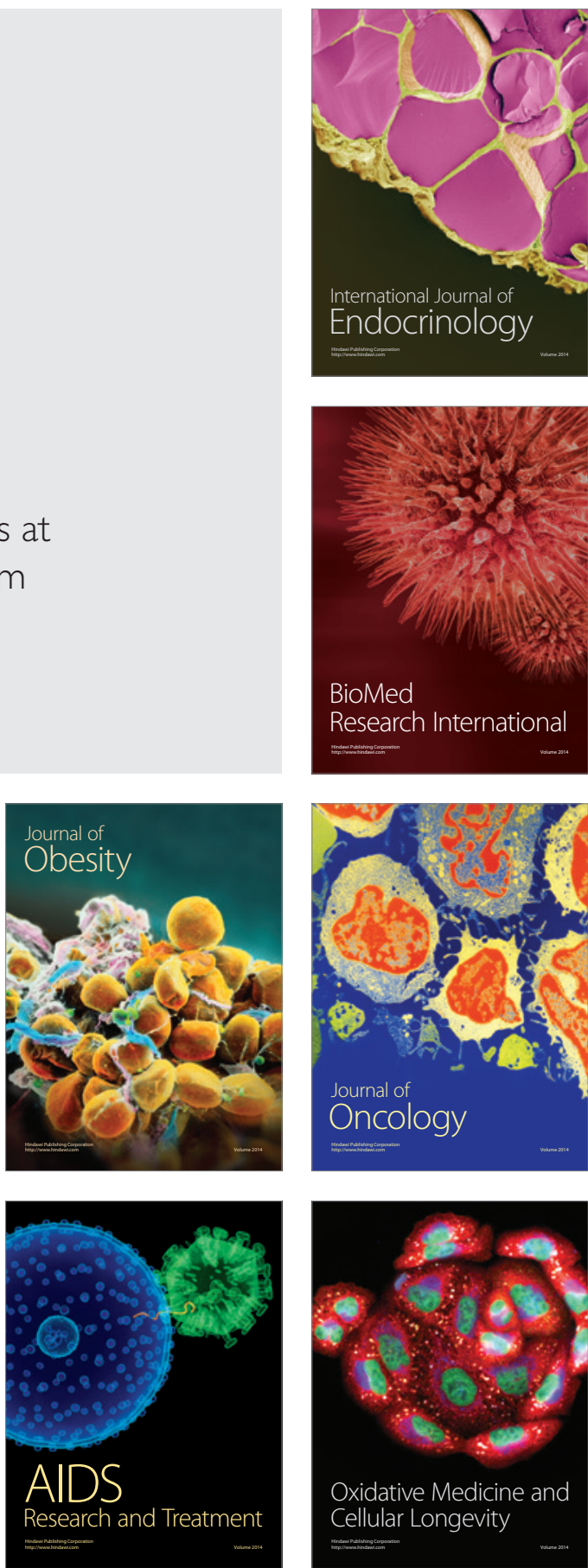